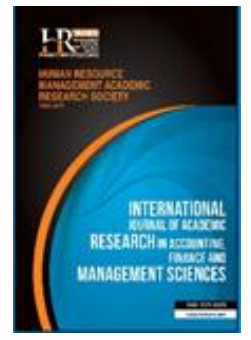

International Journal of Academic Research in Accounting, Finance and Management Sciences

Vol. 9, No.3, July 2019, pp. 211-220

E-ISSN: 2225-8329, P-ISSN: 2308-0337

(C) 2019 HRMARS

www.hrmars.com

To cite this article: Sutomo, H., Budiharjo, R. (2019). The Effect of Dividend Policy and Return on Equity on Firm Value, International Journal of Academic Research in Accounting, Finance and Management Sciences 9 (3): 211220

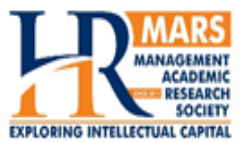

\title{
The Effect of Dividend Policy and Return on Equity on Firm Value
}

\author{
Hadi Sutomo ${ }^{1}$, Roy Budiharjo ${ }^{2}$ \\ ${ }^{1}$ Accounting Study Program, Institut Bisnis dan Informatika, Kesatuan, Jl. Rangga Gading No. 1 Bogor-Indonesia, \\ ${ }^{1}$ E-mail: hadi_sutomo@yahoo.com \\ ${ }^{2}$ Accounting Study Program, Faculty of Economics and Business, Universitas Mercu Buana, Jl. Raya Meruya Selatan \\ Kembangan West Jakarta, ${ }^{2}$ E-mail: budiharjo@mercubuana.ac.id
}

\begin{abstract}
The purpose of this study was to determine the effect of dividend policy which is proxied by the Dividend Payout Ratio on firm value and return equity on firm value. Secondary data were collected in samples from Manufacturing companies listed on the Indonesia Stock Exchange in the period 2014 - 2017. Sampling in this study uses a purposive sampling method with criteria as (1) listed on the Indonesia Stock Exchange in 2014 2017. (2) Publish audited financial statements for the 2014-2017 period in Rupiah. (3) Always has an advantage. Statistical test is done by $t$ test and multiple linear regression analysis, before this test is done first classic assumption test. The results of the study show that: 1) Dividend Payout Ratio has a positive and not significant effect on the value of the company proxy by Price Book Value. 2) Based on the results of the study it can be seen that return on equity has a positive and significant effect on the value of the company proxy by Price Book Value

Key words

ROE, Dividend Policy, Firm Value

Received: 14 Sep 2019 (C) The Authors 2019

Revised: 22 Sep 2019 Published by Human Resource Management Academic Research Society (www.hrmars.com)

Accepted: 27 Sep 2019 This article is published under the Creative Commons Attribution (CC BY 4.0) license. Anyone may Published Online: $\quad 07$ Oct 2019 reproduce, distribute, translate and create derivative works of this article (for both commercial and non-commercial purposes), subject to full attribution to the original publication and authors. The full terms of this license may be seen at: http://creativecommons.org/licences/by/4.0/legalcode
\end{abstract}

\section{Introduction}

Company value is the company's performance which is reflected by the price of shares formed by the demand and supply of capital markets that reflect the public's assessment of the company's performance (Harmono, 2009). Every company must have a goal, both short-term goals and long-term goals. The short term goal of a company is to get the maximum profit with available resources, while in the long run the main goal of a company is to maximize the value of the company (Yuniati et al., 2016).

According to Sartono (2010) the value of a company is the sale value of a company as a business that is operating. The existence of excess selling value above the value of liquidation is the value of the management organization that runs the company. It can be said that the value of the company is the investor's perception of the company, which is often associated with stock prices, because current stock prices reflect investors' assessments of the company in the future. If the company makes a bad decision, the share price will go down. Therefore, the goal of management is to make decisions that can raise share prices, because this will generate wealth for shareholders, thereby increasing the value of the company" (Brigham and Houston, 2010).

Company value can be measured by the Price to book value (PBV) ratio. PBV is a comparison between the market price per share and the book value per share. PBV shows the ability of a company to 
create value for the funds invested by investors. The higher PBV ratio means the company can be declared successful in creating corporate value and owner prosperity (Wihardjo, 2014). Company value is influenced by several internal factors of the company such as dividend policy, debt policy, profitability and investment decisions. These internal factors are often used by potential investors in assessing the company's ability to try to increase the value of the company (Septariani, 2017).

The higher the value of the company the more prosperous its shareholders. The value of a company can be seen from how much the company pays dividends to shareholders. Dividend is the portion of profits distributed to shareholders which can be in the form of cash dividends or stock dividends (Gumanty, 2013), distribution to shareholders of a company in proportion to the number of shares owned by each shareholder (Stice et al., 2010)

The amount of this dividend can affect stock prices. If the dividend paid is high, then the share price tends to be high so the value of the company is also high, conversely, if the dividend paid is small, then the share price of the company is also low (Zahra, 2016).

According to Septariani's research (2017) where Dividend Payout Ratio (DPR) becomes a proxy for dividend policy that has no effect on Price to Book Value (PBV), the ratio used to measure firm value. The results of this study are consistent with Miller and Modigliani's (MM) irrelevant dividend theory in Abdillah (2013) which states that dividend policy is irrelevant, which means it has no influence on firm value. It is interesting because according to Minanari's (2018) research the dividend policy measured by the Parliament has a significant effect on company value. This is adjusted to the Bird in the Hand theory proposed by Gordon and Lintner that in fact investors are much more appreciative of the expected income from dividends than the income expected from capital gains because the risk dividend yield component is smaller.

According to the research of Martikarini (2014) profitability as measured by Return on Equity (ROE) significantly influences the value of the company as measured by PBV. This is due to the large profits that will also provide a good prospect of the company so that it can respond to investors to increase demand for shares. Increased demand for shares will cause the value of the company to increase. According to Umi Mardiyati's (2014) research, Ahmad and Putri (2012) profitability has a significant positive effect on firm value. This means that the higher the value of the profits obtained, the higher the value of the company. Because high profits will give an indication of good company prospects so that it can trigger investors to participate in increasing share demand. The increasing demand for shares will cause the value of the company to increase. Martikarini's research (2014) and Mardiyati's et al., (2012) do not agree with Setyawan's research (2017) which shows that profitability has no effect on firm value. This means that the smaller the profitability of a company will also decrease the value of the company caused by the lack of interest in the company to buy the company's shares.

Based on the background description above, the authors are interested in raising this issue as scientific writing material with the title: "The Effect Of Dividend Policy And Profitability On Corporate Values". Based on the background that has been described above, the author determines the formulation of the problem as follows:

1. Does the dividend policy affect the value of the company?

2. Does Return on Equity affect the value of the company

\section{Literature review}

\subsection{Agency Theory}

According to Brigham and Houston (2015) signal theory is a behavior of company management in giving instructions to investors regarding management's views on the company's prospects for the future. So an increase in the distribution of dividends can be a good signal for investors. An increase in the amount of dividends is considered as a signal that company management is predicting good earnings in the future (Brigham and Houston, 2011). This means that high dividend payments are a positive signal, which indicates a favorable company prospect. Companies that have high profits are also a signal that the company has good prospects in the future (Sujoko and Soebiantoro, 2007).

Signal theory also explains the reasons why companies need to provide financial statement information to external parties. If the manager has confidence that the company's prospects are good, and 
therefore wants to increase share prices, the manager certainly wants to communicate this to investors. Managers can use more debt, which later acts as a more reliable signal. This is because companies that increase debt can be seen as companies that are confident in the company's prospects in the future. Investors are expected to catch these signals, signals that indicate that the company has prospective prospects in the future (Mardiyati et al., 2012).

\subsection{Firm Value}

The company's main goal is to achieve maximum profits or maximum profits. The second objective of the company is to prosper the company owner or shareholders, while the third objective of the company is to maximize the value of the company as reflected in its stock price (Husnan, 2002).

The value of the company is very important because the high value of the company will be followed by the high prosperity of shareholders (Brigham and Gapenski, 1996). The higher the stock price the higher the value of the company. High corporate value is the desire of the owners of the company, because with high value shows the prosperity of shareholders is also high. The wealth of shareholders and companies is presented by the market price of shares which is a reflection of investment decisions, funding (financing), and asset management. Dependent variable in this study is the value of the company measured using Tobin's Q. According to Smithers and Wright (2007) Tobin's Q is calculated by comparing the ratio of market value of company shares with the book value of company equity.

\subsection{Dividend Policy}

Anita and Yulianto (2016) stated that dividend policy is a decision whether the company obtained will be distributed to shareholders as dividends or will be retained in the form of retained earnings to finance investment in the future (Sartono, 2011).

Dividend policy according to Brigham et al. (1999) is a decision about whether to divide profits or keep it to be reinvested into the company. Dividend policy is a decision to determine how much of the company's income will be given to shareholders who are reinvested or retained in the company. In this study, Dividend Policy is measured using Dividend Payount Ratio (DPR).

According to Gumanti (2013) dividend payments are measured by dividing the amount of dividends per share with net income per share. Septariani (2017) explains that the dividend payout ratio is closely related to the company's financial performance. If the company's financial performance is good, the company is able to determine the amount of the dividend payout ratio in accordance with the expectations of shareholders, without ignoring the company's interests to be healthy and growing. The size of the dividend payout ratio can affect the investment decisions of shareholders and also affects the company's financial condition. By looking at this dividend payout ratio, it can be seen whether the company's dividend distributed to investors is better than other companies. Dividend payout ratio is calculated by the formula Dividend Per Share/Earning Per Share or dividend per share divided by earnings per share.

$$
\text { DPR }=\frac{\text { Dividends per Share }}{\text { Earning per Share }}
$$

\subsection{Financial performance}

Profitability according to Sutrisno (2012) is the company's ability to generate profits with all the capital that works in it. Growth in company profitability is one important indicator for investors in assessing the company's future prospects (Tandelilin, 2001). The higher the ability to earn profits, the greater the return expected by investors, thus making the company's value better (Pamadanu, 2013). In this study profitability will be measured using ROE (Return on Equity) because this ratio is used to measure the performance of company management in managing capital available to generate profits after tax. ROE ratio is the ratio of net income to common stock equity, which measures the rate of return on investment of ordinary shareholders. The ROE formula can be calculated as follows:

$$
R O E=\frac{\text { Net Income }}{\text { Equity }}
$$




\section{Methodology of research}

\subsection{Research Model}

Based on the literature review and the results of previous studies and the problems that have been raised, there may be a relationship between the Dividend Policy, the Debt Policy and Profitability to Company Value as a basis for making hypotheses then formulated with the following framework of thought:

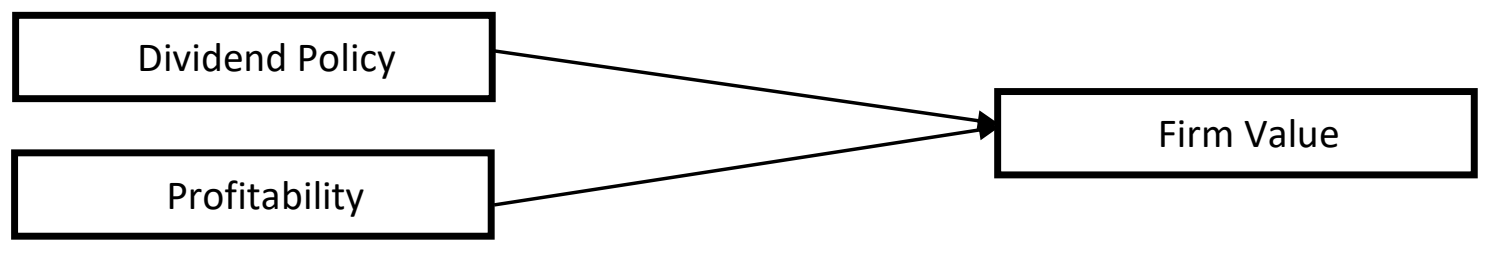

Figure 1. Research Model

Source: the results of the author's processing

\subsection{Hypothesis}

Based on the existing problems and objectives to be achieved, the authors draw three hypotheses, namely:

$\mathrm{H}_{1}=$ Effect of Dividend Policy on Firm Values

$\mathrm{H}_{2}=$ Effect of Profitability on Firm Values

\subsection{Methodology}

The research used in this research is casual associative research. According to Sanusi (2011), associative-causal research is the search for the relationship between two or more variables. The purpose of associative research is to find relationships between one variable and another variable. The population of this study is the companies included in the list of PROPER listed on the Indonesia Stock Exchange in 20152017. The population of this study is companies manufacturing basic and chemical industrial sectors in Indonesia which are listed on the Indonesia Stock Exchange (IDX). From the existing population a certain number of samples were taken by using the Purposive random sampling technique, which is a sampling technique with certain considerations (Suliyanto, 2005). The sample used in this study was selected based on the following criteria:

1. Companies manufacturing basic and chemical industry sectors were listed on the Indonesia Stock Exchange in 2014-2017.

2. The company owned data is complete and in accordance with the variables studied.

\section{Results and Discussions}

Descriptive statistics include minimum, maximum, mean and standard deviation. The research variable data includes the dependent variable, Price to book value (PBV) and independent variables include Dividend Payout Ratio (DPR) \& Return on Equity (ROE). The results of the descriptive statistical analysis are shown in table 1:

1. Company value has an average value of 1.9962. While the standard deviation value is 1.60439 . This indicates that the variable value of the company is normally distributed, because the value of the standard deviation is smaller than the value of the average variable.

2. ISO 14001 has an average value of 0.6173 . While the standard deviation value is 0.48908 . This indicates that the ISO 14001 variable is normally distributed, because the standard deviation value is smaller than the variable average value

3. PROPER has an average value of 0.6812 . While the standard deviation value is 0.11231 . This indicates that the PROPER variable is normally distributed, because the standard deviation value is smaller than the variable average value. 
4. Total Sales Turn Over (TATO) has an average value of 0.9775 . While the standard deviation value is 0.409302 . This indicates that the Total Sales Turn Over (TATO) variable is normally distributed, because the standard deviation value is smaller than the variable average value

5. Net Profit Margin has an average value of 0.1022 . While the standard deviation value is 0.08445 . This indicates that the Net Profit Margin variable is normally distributed, because the standard deviation value is smaller than the variable average value.

Table 1. Descriptive Statistics

Descriptive Statistics

\begin{tabular}{lccccc}
\hline & $\mathrm{N}$ & Minimum & Maximum & Mean & Std. Deviation \\
\hline$D P R$ & 92 & $-204,29$ & 458,15 & 4,3570 & 69,35161 \\
$R O E$ & 92 & $-2,10$ &, 27 &, 0388 &, 28436 \\
$P B V$ & 92 &,- 03 & 11,05 & 1,7190 & 1,87839 \\
Valid N (listwise) & 92 & & & & \\
\hline
\end{tabular}

\section{Classic assumption test}

A model is declared good for predictors if it has the best liner unbiased estimator properties (Gujarati, 1997). Besides that, a regression model is said to be quite good and can be used to predict if it passes a series of econometric assumptions that underlie it.

The classic assumption test is carried out to determine the condition of existing data in order to determine the most appropriate analysis model to use. The classic assumption test used in this study consisted of autocorrelation tests using Durbin-Watson statistics, multicollinearity test using Variance Inflation Factors (VIF) and heteroscedasticity test using the Glejser test.

\section{Multicollinearity Test}

This test aims to test whether the regression model found a correlation between independent variables. A good regression model should not have a correlation between the independent variables. This test is done by using correlations between the independent variables used in the regression equation. If some or all of the independent variables are strongly correlated, multicollinearity occurs.

Table 2. Multicollinearity test

\begin{tabular}{llll}
\multicolumn{2}{l}{ Coefficients $^{\text {a }}$ Model } & \multicolumn{2}{l}{ Collinearity Statistics } \\
\cline { 2 - 4 } & & Tolerance & VIF \\
\hline \multirow{2}{*}{1} & (Constant) & & \\
& DPR_X1 &, 826 & 1,210 \\
& ROE_X2 &, 826 & 1,210 \\
\hline
\end{tabular}

a. Dependent Variable: PBV_Y

The method that can be used to test the presence of multicollinearity is by testing the tolerance value or Variance Inflation Factor (VIF) value. The tolerance value limit is 0.10 and Variant Inflation Factor (VIF) is 10 (Hair et al., 1998). The results of the multicollinearity test show that there are no variables that have a tolerance value of less than 0.10 and there are no variables that have a VIF value of less than 10 . So it can be concluded that there is no multicollinearity in the regression model.

\section{Autocorrelation Test}

The autocorrelation test aims to test whether in the regression model there is a correlation between the confounding errors in period $t$ and the interfering errors in the t-1 period (before). The consequence of autocorrelation in a regression model is that the sample variant does not describe the population variant. Furthermore, the resulting regression model cannot be used to estimate the value of the dependent variable on the value of certain independent variables. 
Table 3. Autocorelation Test

Model Summary

\begin{tabular}{lllllc}
\hline Model & $R$ & R Square & Adjusted R Square & Std. Error of the Estimate & Durbin-Watson \\
\hline 1 &, $589^{a}$ &, 348 &, 338 &, 48416754 & 1,857 \\
\hline
\end{tabular}

a. Predictors: (Constant), DPR, ROE

b. Dependent Variable: PBV

From the table above, the value of Durbin-Watson is 1,857 , so it can be concluded that there is no autocorrelation in this regression model.

\section{Heteroscedasticity Test}

Heteroscedasticity test aims to test whether in the regression model there is an inequality of variance from the residuals of one observation to another. In this study tested using Spearman's Rho. Priyastama (2017) states that this test uses a significant level of more than 0.05 and it is concluded that there is no heteroscedasticity.

Table 4. Heteroscedasticity Test Results

\begin{tabular}{|c|c|c|c|c|c|}
\hline & & & DPR & ROE & PBV \\
\hline \multirow{9}{*}{$\begin{array}{l}\text { Spearman's } \\
\text { rho }\end{array}$} & \multirow{3}{*}{ DPR } & Correlation Coefficient & 1,000 &,- 041 &,- 023 \\
\hline & & Sig. (2-tailed) &. & 697 & 830 \\
\hline & & $\mathrm{N}$ & 91 & 91 & 91 \\
\hline & \multirow{3}{*}{ ROE } & Correlation Coefficient &,- 041 & 1,000 &,- 066 \\
\hline & & Sig. (2-tailed) & ,697 & . & ,532 \\
\hline & & $\mathrm{N}$ & 91 & 91 & 91 \\
\hline & \multirow{3}{*}{ Unstandardized Residual } & Correlation Coefficient &,- 023 &,- 066 & 1,000 \\
\hline & & Sig. (2-tailed) & ,830 & ,532 & . \\
\hline & & $\mathrm{N}$ & 91 & 91 & 91 \\
\hline
\end{tabular}

Normality test

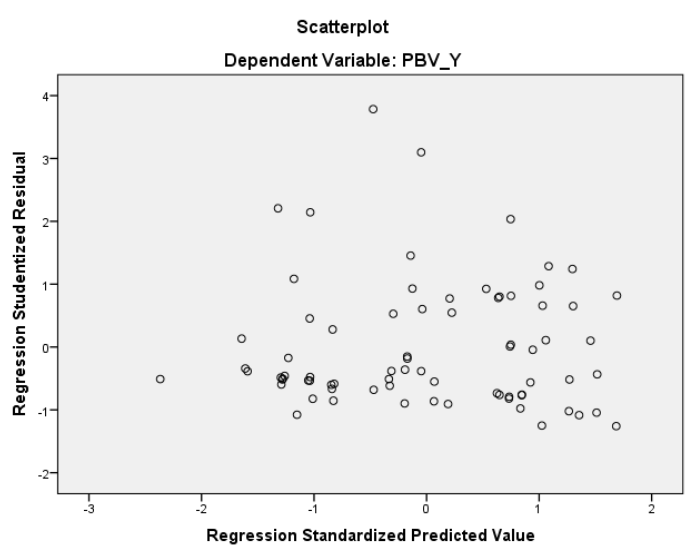

Figure 2. Normality Test Results

By looking at the normal p-plot graph, dots spread around the diagonal line, and the spread follows the direction of the diagonal line. Thus it can be concluded that data from all variables are normally distributed.

Determination Coefficient Test $\left(R^{2}\right)$

This test shows the percentage of the ability of independent variables to explain the variation of the dependent variable. The magnitude of the coefficient of determination from 0 to 1 . The closer to zero the 
magnitude of the coefficient of determination the smaller the influence of the independent variable, on the contrary the closer to a magnitude of the coefficient of determination the greater the influence of independent variables. The test results are seen in the table.

Table 5. Determination Coefficient Test

\section{Model Summary ${ }^{b}$}

\begin{tabular}{lllll}
\hline Model & $R$ & R Square & Adjusted R Square & Std. Error of the Estimate \\
\hline 1 &, $589^{a}$ &, 348 &, 338 &, 48416754 \\
\hline
\end{tabular}

a. Predictors: (Constant), DPR, ROE

b. Dependent Variable: PBV

Based on the table it can be seen that the determination coefficient of Adjusted R Square has a value of 0.338 , so it can be stated that the ability of independent variables DPR \& ROE) in explaining the dependent variable variation (PBV) is very limited, because it approaches 0 .

The value of $R$ Square (R2) is changed to the form of percent, meaning the percentage contribution of the independent variable to the dependent variable. Value R2 The first hypothesis is 0.348 , which means the percentage contribution of environmental performance variables to financial performance variables is $34.8 \%$ while the rest $(100 \%-34.8 \%=65.2 \%)$ is influenced by other variables outside the model.

\section{Simultaneous Significance Test (Test Statistic F)}

Simultaneous significance test ( $F$ test) is used to show whether all the independent variables included in the model have a joint influence on the dependent variable (Ghozali, 2009). If the analysis using the $\mathrm{F}$ test shows that all independent variables simultaneously are explanations of the significance of the dependent variable.

Table 6. Simultaneous Significance Test

ANOVA $^{\mathrm{a}}$

\begin{tabular}{clccccc}
\hline Model & & Sum of Squares & $\mathrm{df}$ & Mean Square & $\mathrm{F}$ & Sig. \\
\hline \multirow{2}{*}{1} & Regression & 2,979 & 2 & 1,490 & 4,326 &, $017^{\mathrm{b}}$ \\
& Residual & 24,791 & 72 &, 344 & & \\
& Total & 27,770 & 74 & & & \\
\hline
\end{tabular}

a. Dependent Variable: PBV_Y

b. Predictors: (Constant), ROE_X2, DPR_X1

\section{Multiple Liner Regression}

In accordance with the results of the research hypothesis which states that between variables have a significant relationship to the dependent variable, multiple linear regression is needed to model the analysis.

Table 7. Statistical Test Result $\mathrm{t}$

Coefficients $^{\mathrm{a}}$

\begin{tabular}{|c|c|c|c|c|c|c|}
\hline & \multirow[t]{2}{*}{ Model } & \multicolumn{2}{|c|}{ Unstandardized Coefficients } & \multirow{2}{*}{$\frac{\text { Standardized Coefficients }}{\text { Beta }}$} & \multirow[t]{2}{*}{$\mathrm{t}$} & \multirow[t]{2}{*}{ Sig. } \\
\hline & & B & Std. Error & & & \\
\hline \multirow{3}{*}{1} & (Constant) & ,729 & 191 & & 3,818 & 000 \\
\hline & DPR_X1 & ,013 & 023 & 071 &, 582 & ,562 \\
\hline & ROE_X2 & 1,578 &, 551 & 351 & 2,864 & 005 \\
\hline
\end{tabular}

a. Dependent Variable: PBV_Y

The regression equation can be written as follows:

$Y=0,729+0,013_{D P R}+1,578_{R O E}+\mathrm{e}$ 
From the regression equation above can be concluded as follows:

1. The constant of 0,729 explains that if the company has Dividend Payout ratio and Retun on equity Ratio, the Company Value proxied by PBV is 0,729 .

2. Dividend Payout Ratio (DPR) regression coefficient of 0.013 states that every increase in DPR is $1 \%$, it will be followed by an increase in company value of $0.013 \%$

3. Return on Equity (ROE) regression coefficient of 1.578 states that every increase in roe is $1 \%$, then it will be followed by an increase in firm value of $1.578 \%$.

\section{Effect of Dividend Policy on Company Value}

The regression coefficient in table 7 shows that Dividend Payout Ratio (DPR) has a positive t count of 0.582 with a probability of 0.562 . This shows that $p$ value $(0.562)>$ significance level $(0.05)$, so $\mathrm{H}_{1}$ cannot be accepted, meaning that Dividend Payout Ratio (DPR) does not have a significant effect on sales value.

These results indicate that Dividend Payout Ratio (DPR) owned by the company have a positive and insignificant effect on Firm Value. This condition is consistent with the results of the Septariani's research (2017) where Dividend Payout Ratio (DPR) becomes a proxy for dividend policy that has no effect on Price to Book Value (PBV), the ratio used to measure firm value.

\section{Effect of Return on Equity on Company Values}

The regression coefficient in table 6 shows that Return On Equity (ROE) has a positive $t$ count of 2.864 with a probability of 0,005 . This shows that $p$ value $(0,005)<$ significance level $(0.05)$, so $\mathrm{H}_{2}$ can be accepted, meaning that Return on Equity (ROE) has a significant effect on company value.

These results indicate that the Return on Equity (ROE) owned by the company have a significant positive effect on Company Value. This condition is consistent with the results of the Martikarini (2014) profitability as measured by Return on Equity (ROE) significantly influences the value of the company as measured by PBV. This is due to the large profits that will also provide a good prospect of the company so that it can respond to investors to increase demand for shares. Increased demand for shares will cause the value of the company to increase.

\section{Conclusions}

Based on the results of the analysis and discussion that has been conducted, the following conclusions can be given:

1. Based on the results of the study it can be seen that the Dividend Payout Ratio has no significant effect on firm value.

2. Based on the results of the study it can be seen that Return on Equity has a significant effect on firm value

\section{Acknowledgment}

For further researchers, further researchers are advised to use more other samples with more diverse characteristics from various industrial sectors and extend the research period. Other studies should also add independent variables that also influence company returns.

\section{References}

1. Abdillah, A. (2013). Analisis Pengaruh Kebijakan Dividen, Kebijakan Hutang, Profitabilitas Dan Keputusan Investasi Terhadap Nilai Perusahaan Manufaktur Di Bei Periode 2009-2012.Fakultas Ekonomi Dan Bisnis, Universitas Dian Nuswantoro, Semarang.

2. Sartono, A. (2010). Manajemen Keuangan Teori Dan Aplikasi. Edisi Keempat, Yogyakarta: Bpfe.

3. Aprilia, A., Yulianto, A. (2016). Pengaruh Kepemilikan Manajerial Dan Kebijakan Deviden Terhadap Nilai Perusahaan. Management Analysis Journal.

4. Bintara, R. (2018). Effect of Profitability, Growth Opportunity, and Capital Structure on Corporate Values with Good Corporate Governance as Moderating Variables (Empirical Study on Manufacturing Companies Listed on the Indonesia Stock Exchange in 2012-2015). Jurnal Profita Mercu Buana University. Vol. 11 No. 2. 
5. Brigham Dan Houston (2010). Dasar-Dasar Manajemen Keuangan(Edisi lii). Jakarta : Salembaempat.

6. Budiharjo, R. (2019). Effect of Environmental Performance and Financial Performance on Firm Value, International Journal of Academic Research in Accounting, Finance and Management Sciences (IJARAFMS), Vol. 9, No.2: 65-73.

7. Septariani, D. (2017). Pengaruh Kebijakan Dividen Dan Kebijakan Hutang Terhadap Nilai Perusahaan, Journal of Applied Business And Economicsvol. 3 No. 3 (Mar 2017) 183-195.

8. Tandelilin, E. (2001). Analisis Investasi Dan Manajemen Portofolio. Yogyakarta: Pt. Bpfe.

9. Haryadi, E. (2016). Pengaruh Size Perusahaan, Keputusan Pendanaan, Profititabilitas, Dan Keputuan Investasi Terhadap Nilai Perusahaan. Universitas Serang Raya, Indonesia. Jurnal Akuntansi, Vol. 3 No. 2 (2016).

10. Fakhruddin, H. S. (2001). Perangkat Dan Model Analisis Investasi Di Pasar Modal. Buku Satu. Elex Media Komputindo. Jakarta.

11. Ghazali, I. (2006). Aplikasi Analisis Multivariat Dengan Program Spss, Badan Penerbit Undip, Semarang.

12. Gumanti, T. A. (2013). Kebijakan Dividen Teori, Empiris, Dan Implikasi. Jakarta: Upp Stim Ykpn.

13. Minanari (2018). Pengaruh Profitabilitas, Manajemen Laba Dan Kebijakan Deviden Terhadap Nilai Perusahaan, Jurnal Profita Vol.11. No. 1. April 2018.

14. Putra, N. S. (2017). Pengaruh Profitabilitas, Solvabilitas ,Ukuran Perusahaan Dan Likuiditas Terhadap Nilai Perusahaan (Studi Pada Perusahaan Manufaktur Di Indonesia). Skripsi,Fakultas Ekonomi \& Bisnis.

15. Martikarini N. (2014). Pengaruh Profitabilitas, Kebijakan Hutang Dan Dividen Terhadap Nilai Perusahaan Manufaktur Yang Terdaftar Di Bursa Efek Indonesia, Jurnal Fakultas Ekonomi Akuntansi Universitas Gunadarma.

16. Nurlela, R. I. (2008). Pengaruh Corporate Social Responsibility Terhadap Nilai Perusahaan Dengan Prosentase Kepemilikan Menejerial Sebagai Variabel Moderating.Simposium Nasional Akuntansi Xi. Pontianak.

17. Pamadanu, D. (2014). Pengaruh Profitabilitas Dan Nilai Perusahaan Terhadap Return Saham Pada Perusahaan Automotive And Allied Products Yang Terdaftar Di Bursa Efek Indonesia, Jurnal. Universitas Negeri Padang.

18. Sudana, M. I. (2011). Manajemen Keuangan Perusahaan. Jakarta: Erlangga.

19. Sujoko, S. U. (2007). Pengaruh Struktur Kepemilikan Saham, Leverage, Faktor Intern Dan Faktor Ekstern Terhadap Nilai Perusahaan, Jurnal Manajemen Dan Kewirausahaan, Vol. 9, No. 1, Maret 2007 : 4148.

20. Sukirni, D. (2012). Kepemilikan Manajerial, Kepemilikan Institusional, Kebijakan Dividend An Kebijakan Hutang Analisis Terhadap Nilai Perusahaan. Accounting Analysis Journal, 2012.

21. Suliyanto. (2005). Analisis Data Dalam Aplikasi Pemasaran, Bogor: Ghalia Indonesia.

22. Sutrisno. (2012). Manajemen Keuangan Teori, Konsep Dan Aplikasi. Yogyakarta: Ekonisia.

23. Mardiyati, U., Ahmad, G. N., Putri, R. (2012). Pengaruh Kebijakan Dividen, Kebijakan Hutang Dan Profitabilitas Terhadap Nilai Perusahaan, Jurnal Riset Manajemen Sains Indonesia, Vol 3 No.1.

24. Wahyudi, H. D., Chuzaimah, C., Sugiarti, D. (2016)."Pengaruh Ukuran Perusahaan, Profitabilitas, Kebijakan Deviden, Dan Keputusan Investasi Terhadap Nilai Perusahaan (Studi Penggunaan Indeks Lq-45 Periode 2010-2014)." Benefit: Jurnal Manajemen Dan Bisnis 1.2 (2016): 156-164.

25. Wiharjo, D. (2014). Analisis Faktor-Faktor Yang Mempengaruhi Nilai Perusahaan. Diponogoro Journal of Accounting Vol.3 No.5.

26. Yuniati, M., Kharis, R., Abrar, O. (2016). Pengaruh Kebijakan Deviden, Kebijakan Hutang Profitabilitas Dan Struktur Kepemilikan Terhadap Nilai Perusahaan Pada Perusahaan Manufaktur Yang Terdaftar Di Bursa Efek Indonesia Periode 2009-2014. Jurnal Of Accounting. Vol. 2 No. 2. 